Journal of Engineering and Science Research 2 (1): 18-22, 2018

e-ISSN: 2289-7127

(C) RMP Publications, 2018

DOI: $10.26666 / \mathrm{rmp}$.jesr.2018.1.4

\title{
Treatment of sago mill effluent for methane production using anaerobic sequencing batch reactor (ASBR)
}

\author{
Rafiqqah Mohamad Sabri, Jamaliah Jahim and Nurleyna Yunus \\ Department of Chemical and Process Engineering, Faculty of Engineering and Built Environment, \\ Universiti Kebangsaan Malaysia, 43600 UKM Bangi, Selanor Darul Ehsan, Malaysia
}

\begin{abstract}
In this research, sago mill effluent was treated using anaerobic sequencing batch reactor (ASBR). Seven HRT from 10 to 1.5 days were tested to evaluate the methane production from sago mill effluent. The findings revealed the highest methane production rate was found at 1.288 L CH4/L reactor. d under HRT of 2 days The results showed that COD removals decreased from 70\% to 47\% as HRT was reduced from 10 to 2 days. The HRT 1.5 days was found critical for the studied system, which leads to decreased in methane production, yield and COD removal. Overall, ASBR was capable to treat sago mill effluent in producing methane by means of anaerobic digestion.
\end{abstract}

Key words: Sago mill effluent, Anaerobic digestion, Methane

\section{INTRODUCTION}

Sago palm is one of the most essential of few type species of palm that is useful for starch yield. It has been utilized in South East Asia region for no less than 700 years [1]. A palm of sago may produce between 150 to $300 \mathrm{~kg}$ of dry starch. At an average consumption of $1000 \operatorname{logs} /$ day, a minimal of 400 tons of slurry effluent is generated for a typical sago factory [2]. Massive amounts of waste water, bark of sago trunk, and fibrous residue commonly called as hampas are produced during sago starch production [3]. As reported by Chew and Shim [4], about 5-11 tons of hampas is released daily from each mill in Sarawak. Currently, these residues which are mixed together with wastewater are either washed off into nearby streams or deposited in the factory's compound. These circumstances, in time, may potentially lead to serious environmental problems.

Therefore, anaerobic digestion is suggested to be an effective way to treat wastewater from sago industry. It is a biological process whereby bacteria degrades organic waste such as food waste, municipal waste and other types of waste into biogas (mainly methane and carbon dioxide) in oxygen free environment. The purpose of this research was to study the performance of anaerobic digestion of sago mill effluent for methane

production in an anaerobic sequencing batch reactor (ASBR

\section{EXPERIMENTAL PROCEDURE}

\section{Substrate and inoculum}

Sago mill effluent (SME) was used as substrate and prepared fresh in laboratory. Sago pith was liquefied in a heavy duty blender with addition of tap water at standard ratio of 1:4. The resulting liquid mixture was filtered with muslin cloth to settle the starch particles. The filtration and settling process was done thrice. The final supernatant was stored in bottles at $4^{\circ} \mathrm{C}$ and to be used within 3 days. The $\mathrm{pH}$ of sago mill effluent was adjusted to 7.50 and added with homogenous solution such as potassium dihydrogen phosphate, $\mathrm{KH}_{2} \mathrm{PO}_{4}$, potassium hydrogen phosphate, $\mathrm{K}_{2} \mathrm{HPO}_{4}$, cysteine, dextrose and ammonium hydrogen carbonate, $\mathrm{NH}_{4} \mathrm{HCO}_{3}$, sodium hydrogen carbonate, $\mathrm{NaHCO}_{3}$. Enriched sago sludge was used as methanogenic inoculum.

\begin{abstract}
ASBR operation
Experiment was performed at mesophilic condition $\left(37^{\circ} \mathrm{C}\right)$ in $1 \mathrm{~L} \mathrm{ASBR}$ reagent bottle with working volume of $800 \mathrm{~mL}$. About $640 \mathrm{~mL}$ of SME was mixed with 160 $\mathrm{mL}$ of methanogenic inoculum. The bottle was capped and flushed with nitrogen gas for 10 mins to create oxygen free condition. Initially, the experiment was
\end{abstract}

Corresponding Author: Rafiqqah Mohamad Sabri . Department of Chemical and Process Engineering, Faculty of Engineering and Built Environment, Universiti Kebangsaan Malaysia, 43600 UKM Bangi, Selanor Darul Ehsan, Malaysia, 0195407616 
conducted in batch mode for 20 days to acclimatize the methanogenic inoculum to the substrate. Then, it was switched to ASBR mode started with an hydraulic retention time (HRT) of 10 days that is equal to organic loading rate (OLR) $1.39 \mathrm{~kg} \mathrm{COD} / \mathrm{m}^{3}$. d. Then the HRT was decreased stepwise to $8,6,4,3,2$ and 1.5 days. ASBR was fed once in $24 \mathrm{hrs}$ consisted of $10 \mathrm{~min}$ feeding, $22.5 \mathrm{~h}$ reaction, $1 \mathrm{~h}$ settling and $10 \mathrm{~min}$ decanting.

\section{Analytical methods}

$\mathrm{pH}$, COD, TS VS, TSS VSS were analyzed according to standard methods. The biogas volume produced was measured using water displacement method. $500 \mu \mathrm{L}$ gas tight syringe (Hamilton, USA) was taken from the headspace of reactor. The composition of gas was measured using a gas chromatography (GC) (Hewlett Packard 5890) equipped with a thermal conductivity detector (TCD). The GC was fitted in series with a stainless steel molecular sieve column (10 ft 45/60) and Porapak Q packed column (9 ft 80/100). The injector, oven and detector temperatures were set at $90^{\circ} \mathrm{C}, 50^{\circ} \mathrm{C}$ and $200^{\circ} \mathrm{C}$, respectively. Helium was used as the carrier gas with a flow rate of $18.7 \mathrm{~mL} / \mathrm{min}$.

For volatile fatty acids (VFA) and alcohol were analyzed using a gas chromatograph GC (Hewlett Packard 5890) equipped with flame ionization detector (FID). The column used was HP-FFAP (50 m length $\mathrm{x}$ $0.2 \mathrm{~mm}$ ID $\times 0.33 \mu \mathrm{m}$ film thickness) with helium as carrier gas. Injector and detector temperature were maintained at $270^{\circ} \mathrm{C}$ and $200^{\circ} \mathrm{C}$ respectively. Oven temperature was set to run at $60^{\circ} \mathrm{C}$, held for $4 \mathrm{~min}$, then ramped at $6^{\circ} \mathrm{C} / \mathrm{min}$ to $92^{\circ} \mathrm{C}$ followed by a $20^{\circ} \mathrm{C} / \mathrm{min}$ ramping to $150^{\circ} \mathrm{C}$, then ramped again at a slower rate of $6^{\circ} \mathrm{C} / \mathrm{min}$ to $175^{\circ} \mathrm{C}$ before finally increasing the temperature to $210^{\circ} \mathrm{C}$ at a rate of $30^{\circ} \mathrm{C} / \mathrm{min}$ to completely remove remaining compound in the column. The separation of the primary volatile fatty acids and related solvents were obtained within $19.57 \mathrm{~min}$.

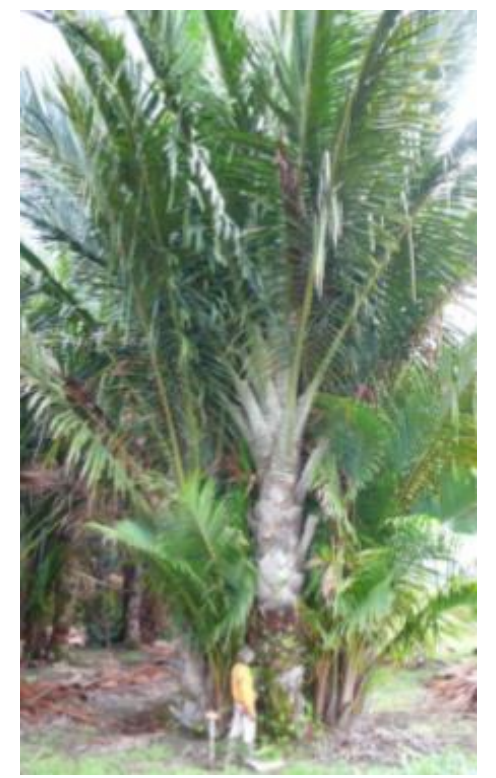

Fig 1 The sago palm (Metroxylon sp.)

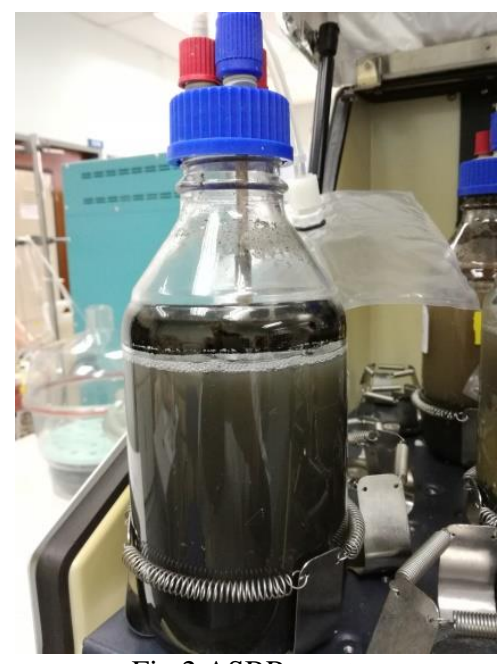

Fig 2 ASBR reactor

\section{CALCULATION}

COD removal is the amount of chemical oxygen demand loading to be degraded from the system. COD removal efficiency is calculated based on Equation $1:$

$$
\text { COD removal }=\frac{\text { COD inf-COD eff }}{\text { COD inf }} \times 100
$$

Where: $\mathrm{COD}$ eff $=$ effluent COD $(\mathrm{mg} / \mathrm{L})$

COD inf $=$ influent $\operatorname{COD}(\mathrm{mg} / \mathrm{L})$

Hydraulic retention time (HRT) is HRT expressed in day or hour and calculated by Equation 2 in a ASBR system

$$
\mathrm{HRT}=\frac{\mathrm{Vr}}{\mathrm{Q}}
$$


$\mathrm{Vr}=$ Effective volume of the reactor, $\mathrm{L}$

$\mathrm{Q}=$ Influent flow rate, $\mathrm{L} / \mathrm{d}$

\section{RESULT AND DISCUSSION}

\section{Methane and biogas volume}

Single stage process was performed by utilizing sago mill effluent as influent for methane production. Seven experimental runs of different HRTs $(10,8,6,4,3,2$ and 1.5 days) were tested. Table 1 summarizes the steady state results obtained during the course of experiment. The biogas volume was found to increase from 325 to $1828 \mathrm{ml}$ as HRT was decreased from 10 to 2 days. As reported by Ndegwa, Hamilton, Lalman and Cumba [5], the increment in biogas was predicted as HRT is reduced due to the increase in loading rate and thus further supply of degradable substrate. When, HRT is progressed further to 1.5 days, a decline trend in biogas volume was observed.

Methane production plays a vital part in anaerobic digestion that defines the efficiency of anaerobic digestion. At the beginning of the experiment, methane volume was low because of low OLR and the evolved methane increase with the increment of OLR or short HRT. As can be seen from Table 2, the volume of methane increased from $145 \mathrm{ml}$ to $1043 \mathrm{ml}$ as a result of less HRT was applied. Generally, methane content was found to be within the range of $33 \%$ to $46 \%$. The same trend as biogas volume was observed in methane volume as HRT going down to 1.5 days.

\section{Methane production rate and Methane yield}

The methane production rate (MPR) and methane yield (MY) was found to increase steadily from initial experiment start-up to approximately $0.344 \mathrm{~L}$ $\mathrm{CH}_{4} / \mathrm{L}_{\mathrm{ww}}$ and $0.1867 \mathrm{~L} \mathrm{CH}_{4} / \mathrm{g} \mathrm{COD}$ removed until day 56 of fermentation, respectively. After HRT were reduced from 8 to $6 \mathrm{~d}$ at day 47, the MPR and MY was found to decreased until day 82 of fermentation possibly due to the variation of sago mill effluent being used. Then, MPR and MY started to increase gradually at day 83 when HRT was further decreased from $4 \mathrm{~d}$ to $3 \mathrm{~d}$. At HRT $2 \mathrm{~d}$, the MPR and MY continuously increase to $1.288 \mathrm{~L} / \mathrm{L} \mathrm{CH}_{4}$.d and $0.2569 \mathrm{~L} \mathrm{CH}_{4} / \mathrm{g} \mathrm{COD}$ removed, respectively. Meanwhile at HRT of 1.5 days, MPR decreased to $0.939 \mathrm{~L} \mathrm{CH}_{4} / \mathrm{L}_{\mathrm{ww}}$. $\mathrm{d}$ though the MY keep continue to rise to $0.3377 \mathrm{~L} \mathrm{CH}_{4} / \mathrm{g} \mathrm{COD}_{\text {removed. Thus, it }}$ can be concluded that an HRT of 1.5 days was too short to allow substantial methane production in this system.

\section{$p H$, VS and COD removal}

In general, COD removal showed a decreasing trend from $70 \%$ to $47 \%$ as HRT is reduced from 10 to 2 days. This could be attributed to biomass loss as HRT is reduced thus contributing to the decreased in substrate removals [6]. Although the biogas and methane volume were increased, it takes time for the reactor to stabilize as the COD removal started to decrease which then followed by the increase in COD concentration of the effluent which eventually would affect the performance of COD removal in the reactor.

The $\mathrm{pH}$ range in the effluent was all above 7.0 which are optimal for production of methane. VS and VSS are crucial criteria when loading anaerobic reactor as both represents solid material suspended and the population size of bacteria within the activated sludge process respectively. As illustrated in Figure 7, it can be seen that the concentration of solid biomass was increasing. This behavior can be explained when HRT is declined, the organic loading increases accordingly and biomass synthesis is greater [6]. It can be observed the ASBR was capable to hold up to $23000 \mathrm{mg} / \mathrm{liter}$ of biomass concentration. The high MLVSS of the reactors proves that the ASBR system has the ability to support high solids in the system and allowing efficient treatment of low-strength wastewater [7].

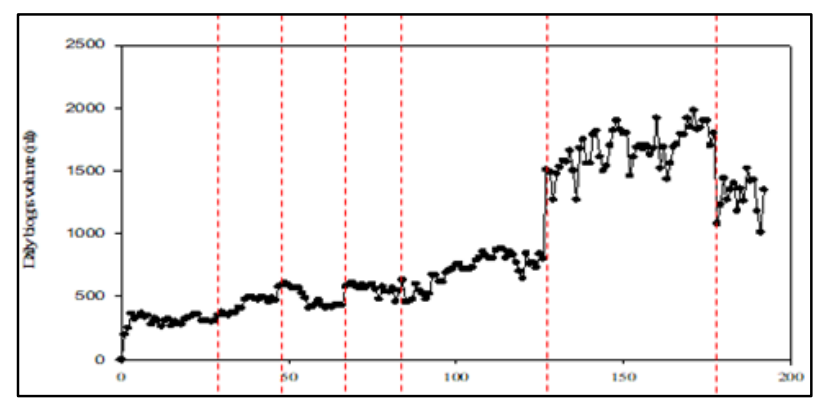

Figure 3 Daily biogas volumes

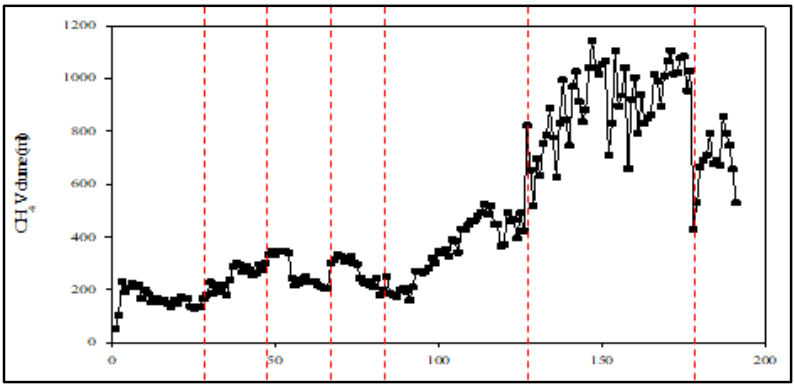

Figure 4 Methane volume

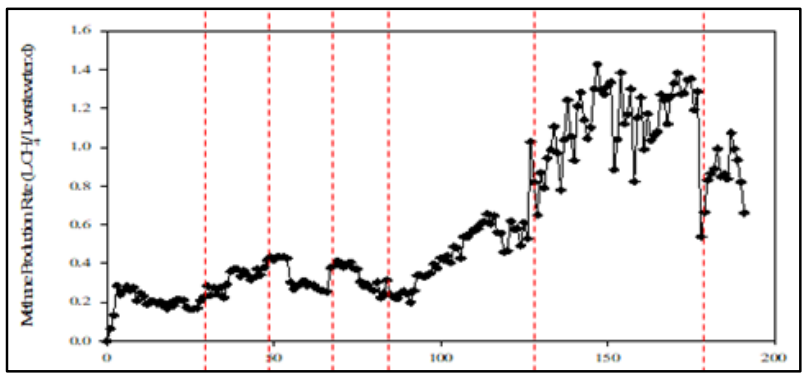

Figure 5 Methane production rate 


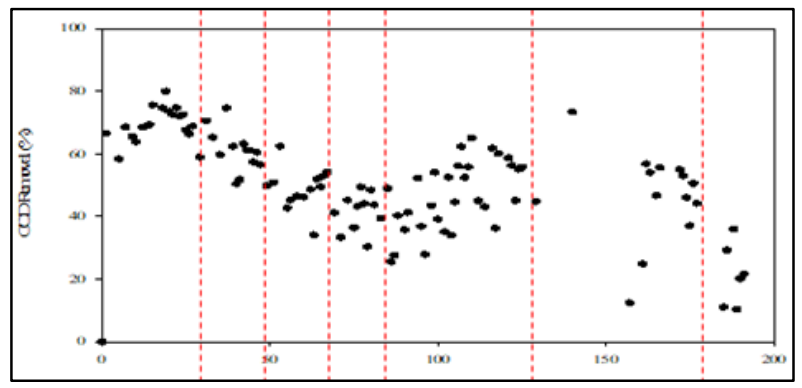

Figure 6 COD removal

\section{Volatile fatty acid (VFA)}

At any given HRT, ethanol was the most abundant alcohols in the influent of ASBR. Unlike other studies, ethanol production was relatively high in this experiment, possibly due to the properties of sago mill effluent itself. The highest VFA reduction was $72 \%$ at HRT 8 days, and the lowest was $43 \%$ at HRT 3 days. All VFAs were degraded by microbes to acetic acid before converting to $\mathrm{CH}_{4}$ according to sequence acetic acid $>$ ethanol $>$ butyric acid $>$ propionic acid [8] . Meanwhile, propionic acid was least detected in the reactor.

\section{CONCLUSION}

The Anaerobic Sequencing Batch Reactor (ASBR) has been shown to effectively treat sago mill effluent. High organic matter removal efficiencies (up to $70 \%$ COD removal) can be achieved in single stage digestion. Methane gas was produced in the range of $145 \mathrm{~mL}$ to $1043 \mathrm{~mL}$. The highest methane production rate obtained was at $1.288 \mathrm{~L} \mathrm{CH}_{4} / \mathrm{L}_{\text {reactor. }} \mathrm{d}$ under HRT of 2 days.

\section{ACKNOWLEDGMENTS}

The authors acknowledge the financial support from Universiti Kebangsaan Malaysia, UKM Bangi, Selangor, Malaysia and CRAUN Research Sdn Bhd Kuching, Sarawak, Malaysia for laboratory, facilities and chemicals provided.

\section{REFERENCES}

[1] C. Oates, A. Hicks, Sago Starch Production in Asia and the Pacific - Problems and Prospects, in: K.

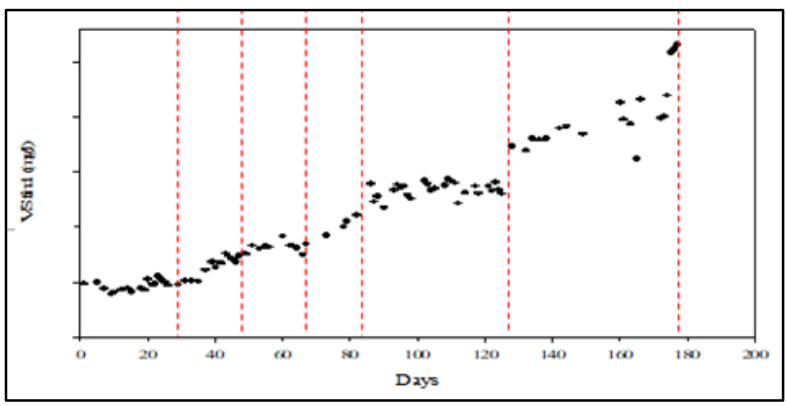

Figure 7 Volatile solids concentration

Kainuma, M. Okazaki, Y.Toyoda, J.E. Cecil (Eds.) Proceedings of the International Symposium on Sago: New Frontiers of Sago Palm Studies, Universal Academy Press Inc, Tsukuba, Japan, 2001, pp. 27-36.

[2] M.C. Lo, Sago starch factory effluent: salvaging a potential pollutant, 2008. http://www.researchsea.com/html/article.php/aid/3069/ cid/2. (Accessed 5 October 2017).

[3] K. Apun, K. Bujang, B.C. Jong, M.A. Salleh, Enzymatic activities of locally isolated bacteria on sago waste residue, in: C. Jose, A. Rasyad (Eds.) Proceeding of the 6th International Sago Symposium Sago: The Future Source of Food and Feed, Indonesia, 1996, pp. 127-134.

[4] T. Chew, Y. Shim, Management of sago processing wastes, Waste management in Malaysia-current status and prospects for bioremediation (1993).

[5] P.M. Ndegwa, D.W. Hamilton, J.A. Lalman, H.J. Cumba, Effects of cycle-frequency and temperature on the performance of anaerobic sequencing batch reactors (ASBRs) treating swine waste, Bioresour Technol 99(6) (2008) 1972-80.

[6] G.C. Banik, R.R. Daguet, ASBR treatment of low strength industrial wastewater at psychrophilic temperatures, Water Science and Technology 36(2) (1997) 337-344.

[7] U.J. Ndon, R.R. Dague, Effects of temperature and hydraulic retention time on anaerobic sequencing batch reactor treatment of low-strength wastewater, Water research 31(10) (1997) 2455-2466.

[8] Y. Wang, Y. Zhang, J. Wang, L. Meng, Effects of volatile fatty acid concentrations on methane yield and methanogenic bacteria, Biomass and Bioenergy 33(5) (2009) 848-853. 
Rafiqqah Mohamad Sabri /Journal of Engineering and Science Research, 2 (1) 2018, Pages: 18-22

Table 1 Average steady state data in single stage experiment

\begin{tabular}{|c|c|c|c|c|c|c|c|c|}
\hline & Unit & & & & & & & \\
\hline HRT & days & 10 & 8 & 6 & 4 & 3 & 2 & 1.5 \\
\hline OLR & $\mathrm{kg} \mathrm{COD} / \mathrm{m}^{3} . \mathrm{d}$ & $1.39 \pm 0.04$ & $2.21 \pm 0.07$ & $2.21 \pm 0.29$ & $3.26 \pm 0.13$ & $3.69 \pm 0.16$ & $7.61 \pm 0.42$ & $11.23 \pm 1.46$ \\
\hline Effluent $\mathrm{pH}$ & - & $7.84 \pm 0.10$ & $7.44 \pm 0.05$ & $7.42 \pm 0.12$ & $7.00 \pm 0.10$ & $7.11 \pm 0.02$ & $6.97 \pm 0.02$ & $7.26 \pm 0.42$ \\
\hline Biogas volume & $\mathrm{mL} / \mathrm{d}$ & $325 \pm 27.57$ & $481 \pm 15.24$ & $429 \pm 9.17$ & $528 \pm 48.34$ & $790 \pm 45.87$ & $1828 \pm 74.41$ & $1362 \pm 123.68$ \\
\hline Methane volume & $\mathrm{mL}$ & $145.83 \pm 18.13$ & $\begin{array}{c}275.24 \pm \\
16.69 \\
\end{array}$ & $\begin{array}{c}216.97 \pm \\
12.49 \\
\end{array}$ & $\begin{array}{c}218.05 \pm \\
22.31 \\
\end{array}$ & $\begin{array}{c}454.07 \pm \\
39.09\end{array}$ & $\begin{array}{c}1043.00 \pm \\
76.10 \\
\end{array}$ & $\begin{array}{c}735.00 \pm \\
79.22 \\
\end{array}$ \\
\hline Methane content & $\%$ & $35.80 \pm 1.70$ & $45.80 \pm 2.82$ & $41.10 \pm 3.14$ & $33.10 \pm 2.55$ & $45.90 \pm 2.59$ & $45.10 \pm 0.56$ & $43.20 \pm 1.84$ \\
\hline $\begin{array}{l}\text { Methane production } \\
\text { rate }\end{array}$ & $\mathrm{L} \mathrm{CH}_{4} / \mathrm{L}_{\mathrm{ww}} \cdot \mathrm{d}$ & $0.182 \pm 0.02$ & $0.344 \pm 0.02$ & $0.271 \pm 0.02$ & $0.273 \pm 0.03$ & $0.568 \pm 0.05$ & $1.288 \pm 0.06$ & $0.939 \pm 0.10$ \\
\hline COD removal & $\%$ & $70.42 \pm 3.23$ & $59.25 \pm 4.08$ & $47.49 \pm 7.68$ & $43.26 \pm 7.62$ & $54.24 \pm 5.25$ & $47.68 \pm 6.60$ & $21.39 \pm 11.23$ \\
\hline Methane yield & $\begin{array}{c}\mathrm{L} \mathrm{CH}_{4} / \mathrm{g} \mathrm{COD} \\
\text { removed } \\
\end{array}$ & $0.1307 \pm 0.01$ & $0.1867 \pm 0.03$ & $\begin{array}{c}0.1872 \pm \\
0.05\end{array}$ & $0.1450 \pm 0.03$ & $0.2054 \pm 0.04$ & $0.2569 \pm 0.05$ & $0.3377 \pm 0.20$ \\
\hline
\end{tabular}

